\title{
Euro-vote lifts block on biotech patents
}

[MUNICH] A long-standing question at the European Patent Office (EPO) about whether it is legally entitled to grant patents on transgenic animals and plants could soon be resolved, following last week's approval by the European Parliament of revised rules on the legal protection of biotechnological inventions.

The EPO has almost 2,000 such applications in abeyance, following a decision two years ago that the exclusion of plant and animal varieties from patentability by the European Patent Convention of 1973 is sufficient to reject a patent on a plant or animal that has been genetically modified.

But the draft European directive explicitly allows patenting of life, including human genes, provided that a truly inventive step and industrial use can be proved, and provided that the procedures involved are within defined ethical limits.

It also requires the European Commission to set up a bioethics committee, which would report annually to the parliament on issues concerning the patenting of biotechnological inventions (see panel).

The directive must be approved by the European Council of Ministers in November, before returning to parliament for its second reading, expected early next year. But the council's support for the initial draft, the modifications to which have been generally accepted by the commission, means that a successful conclusion seems virtually guaranteed.

The pharmaceutical industry has welcomed the parliamentary vote, saying that it

will help Europe's biotechnology sector to catch up with the United States and Japan. But it has been criticized by environmentalists, who continue to oppose patents on novel life-forms.

The first draft of the directive was unexpectedly rejected by the parliament in 1995 because of ethical concern about patenting of life and human genes, as well as concern that it could impinge on farmers' privilege to breed or propagate stock (see Nature 374, 103; 1995).

The commission, which drafts all European Union directives, was more careful with the text in its second attempt. It consulted industry, pressure groups and other stakeholders before putting pen to paper (see Nature 379, 197; 1996), and included additional clauses to safeguard ethical standards.

But members of the parliament still tabled hundreds of amendments, reflecting a controversy that cuts across political party lines. And, in a unique move, the parliamentary Committee on Research, Technological Development and Energy declined to give an opinion of the directive before its first reading because of disagreements about which amendments to recommend.

As now approved by the parliament, the draft directive excludes patents on procedures for human reproductive cloning and germline therapy, and methods using human embryos. But many opponents of the directive remain upset that patenting of any form of life should be allowed. "This is a sad day for human respect for life," said a spokesman for Greenpeace after the vote.

\section{...but parliament wants closer scrutiny}

[MUNICH] The European Parliament wants to have more influence over the debate on bioethics in Europe, and would like ethical committees to be more concerned about the effects of biotechnological research on society.

An amendment to the European Commission's draft directive on the legal protection of biotechnological inventions, which was approved last week at its first parliamentary reading (see above), urges the commission to establish a committee on the ethics of biotechnology. This would report to parliament annually on all ethical questions relating to biotechnology. Details of its responsibilities have yet to be defined.

The proposal is closely connected to a recent parliamentary resolution extending to the end of the year the mandate of the commission's existing Group of Advisors on the Ethical Implications of Biotechnology (GAEIB), which was due to expire later this month.

The resolution called for the commission to renew and clarify GAEIB's role, in close consultation with parliament. It formally commended the group, which was set up in 1991, for contributing to the public debate on bioethics through its series of reports. But it also argued that "too much attention has been paid to the interests of research and not enough to the possible effects on society".

The commission is likely to recommend to parliament that the committee demanded by the draft directive should be closely connected with, or identical to, GAEIB, but details have yet to be formulated.

Noëlle Lenoir, a member of the French constitutional court who chairs GAEIB, says that the group would welcome what she sees as a natural expansion of its role to cover ethical issues relating to patenting of biotechnological inventions. A. A.

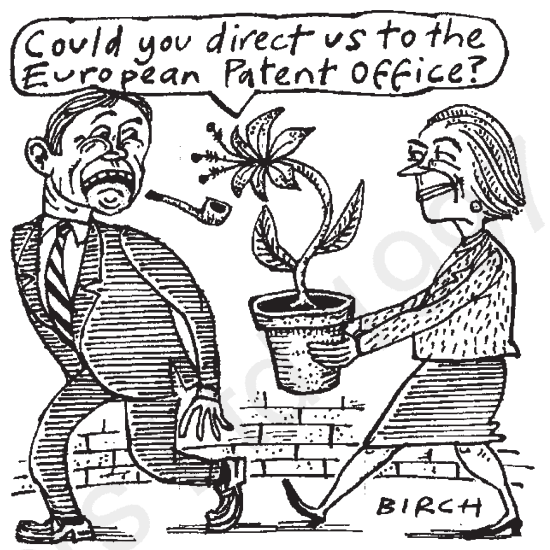

Peter Stevenson, political and legal director of the British pressure group Compassion in World Farming (CIWF), says he is "deeply disappointed" that parliament has voted to allow animals to be patented. But he welcomes a clause that excludes patents on processes for modifying the genetic identity of animals "which are likely to cause them suffering or physical handicaps without any substantial medical benefit to man or animal".

The addition of the word 'medical' by the parliament means that benefits to agriculture alone will not necessarily outweigh any proven suffering to an animal genetically engineered, for example, to overproduce growth hormone, as grounds for rejecting a patent.

Stevenson says that CIWF has filed an opposition to a patent issued to the Australian company Bresagen on a method for producing transgenic pigs with extra growth hormone genes, claiming that such animals suffer joint disease, gastric ulcers and diabetes.

A spokesman for the EPO says the exclusion clause is likely to cause problems for patent lawyers because of the difficulty of legally interpreting what constitutes a physical handicap. In principle, the EPO is not formally bound by EU directives, as it is not an EU body. It was established by a separate convention with its own rules on what may be considered patentable. But in practice the directive would have a profound effect on EPO policy.

Eighteen months ago, opponents of patents on life, who had never managed successfully to oppose a patent on ethical grounds, exploited a loophole in the EPO's convention and put an abrupt stop to issuing of any new patents on transgenic plants and animals.

The convention, which was drawn up in the early 1970s, allows animals and plants to be patented in principle, but excludes animal and plant varieties from patentability, to allow breeders to claim their traditional nonpatent rights to new varieties. 
In 1995 an EPO board of appeals ruled against a patent issued to the Belgian company Plant Genetics Systems (PGS) on a procedure for producing plants containing a new gene conferring resistance to herbicides based on glutamine synthase inhibitors, which also covered their progeny. The patent office accepted opponents' arguments that a transgenic plant can also be considered a plant variety, and is therefore not patentable.

Until this precedent is overturned by a further decision by an appeals board, the EPO cannot legally issue further patents on transgenics. A backlog of around 1,200 patent applications for plants, and 500 or 600 on animals, has since built up.

The next case to be brought to the EPO board of appeals, scheduled for October, will consider an appeal from the Swiss company Novartis against the rejection - following the PGS case - of its patent application for a process for creating transgenic plants containing genes conferring pathogen resistance, and again covering their progeny.

The board will refer to the draft directive to help it to interpret the ambiguity in the EPO's rules created by the advent of genetic engineering. The draft states unambiguously that "inventions which concern plants or animals may be patented if the practicability of the invention is not technically confined to a particular plant or animal variety".

In the unlikely event that the board of appeals rejects this interpretation and upholds the ruling in the PGS case - that animals and plants are not legally distinguishable from their varieties - it would cause a major conflict, as EU member states, which form the core of EPO members, will be required to incorporate the directive in national legislation.

Alison Abbott

\section{Swiss researchers facing 'anti-transgenics' vote}

[MUNICH] Swiss scientists are warning that biomedical research in universities will be seriously harmed if a referendum next year calling for restrictions on genetic engineering - including a ban on the use of transgenic animals - wins approval.

A recent survey by the Swiss Societies for Experimental Biology (SSEB) found that at least 2,000 researchers involved in about 500 research projects would be directly affected by a proposed ban on the use of transgenic animals and field trials of genetically modified plants.

The referendum also proposes a ban on patenting genetically modified animals and plants, and demands that scientists demonstrate in advance that their research is of value to society and will not pose an environmental risk. Scientists would have to show that there are no alternative methods, and agree to observe approved ethical standards.

The survey indicates that Switzerland would quickly lose its high ranking in international genetics research if the proposals go through. "Aban on transgenic animals would be a virtual death blow for our research," says Rolf Zinkernagel, director of the Institute for Experimental Immunology at the University of Zurich, where 80 per cent of research projects involve transgenic animals.

Zinkernagel says that he would consider leaving Switzerland if the referendum resulted in a ban. "But the real victims would be the young generation of Swiss scientists who would be deprived of access to essential mol- ecular biological techniques," he says.

The referendum was initiated in 1992 by 70 pressure groups opposed to biotechnology. According to Switzerland's direct democracy rules, any proposal for a constitutional amendment that secures the signatures of 1.5 per cent of the population must be put to a vote. If there is a simple majority, with a majority of cantons voting in favour, the proposed changes are incorporated into law.

The pharmaceutical industry has already launched an advertising campaign supporting the use of genetic engineering techniques in research in Switzerland. Christian Manzoni, a spokesman for a campaign launched by Hoffman-La Roche and Novartis, says that a 'yes' vote would be "a catastrophe for the industry". Manzoni warns that, if all research using genetic engineering techniques had to be done outside Switzerland, the companies would lose control over both ethical standards and methodologies.

University research departments are even more worried. "The pharmaceutical industry can take its genetic research abroad," says Peter Mani, director of the department of gene technology and society at SSEB. "But basic research at universities would suffer considerably from the proposed ban."

Previous surveys have shown that threequarters of the Swiss population are against field trials of genetically modified organisms, novel foods and cloning, although a majority are in favour of medical applications of biotechnology. QuirinSchiermeier

\section{Russian minister tells academy: streamlining must continue}

[MOscow] The Russian Academy of Sciences (RAS) is to merge some institutes whose directors are not RAS members with those headed by academicians. This follows a meeting with Vladimir Bulgak, vice prime minister for science and high technology in the Russian cabinet, who insisted that the number of inefficient institutes should be reduced so that the remaining institutes can be more effectively supported.

Bulgak appears determined to continue the reforms started by the former minister of science and technology policy, Boris Saltykov. Reforms had, however, stalled under Saltykov's successor, Vladimir Fortov. Fortov is vice-president of the RAS, academic secretary of its physics department and director of an academy institute. Many feel there is a conflict of interest between his academy role and his responsibility for the whole of the science budget.

In the new move, the Institute of
Spectroscopy in Troitsk, near Moscow, for example, which is relatively successful but whose director, Vladilen Letokhov, has failed to be elected to the academy, will be incorporated into the department of optics of the Physical Institute, which is in financial trouble but is headed by an academician.

The situation is further complicated by the recent election to the academy of Michail Kirpichnikov, chief of the cabinet's science and education department (see Nature 387, $535 ; 1997)$. Universities in particular are worried that Kirpichnikov will support the academy's interests but not necessarily those of other scientific institutions.

Bulgak told a recent press conference that the state will provide 13,000 billion rubles (US\$2,250 billion) a year for research, while the deputy finance minister, Izosim Molchanov, promised at a business meeting held by Bulgak that current debts to scientific institutions will be paid.
Bulgak is keen to convince others that change is necessary. The average salary of a Russian scientist is about 700,000 rubles (US\$120) a month. Trade unions want this increased to 1 million rubles. But Bulgak said that, to achieve this, "scientific institutions have only two options: earn more in Russia and abroad, or reduce staff".

His suggestion that some institutes should be closed has political opponents. According to Vladimir Babkin, an expert in science and education with the State Duma (the Russian parliament's lower chamber), "the government's attitude towards national science can be compared to that of the physician who said that the best remedy against headache is a guillotine".

But politicians have not suggested any other way out of the problems facing Russian science, and their criticism of the government is widely seen merely as a way of winning public sympathy.

Carl Levitin 